DOI: $10.2478 / \mathrm{v} 10025-010-0034-5$

JOURNAL OF WATER

AND LAND DEVELOPMENT

J. Water Land Dev. No. 13a, 2009: 273-282

\title{
The needs and possibilities of constructing on site wastewater treatment plants in forester's lodges
}

\author{
Agnieszka KARCZMARCZYK ${ }^{1)}$, Stawomir SKOWRON ${ }^{2)}$, \\ Józef MOSIEJ ${ }^{1)}$, Anna BARYŁA ${ }^{1)}$
}

\footnotetext{
1) Warsaw Agricultural University, Department of Environmental Improvement, Nowoursynowska 159, 02-776 Warsaw, Poland; e-mail: agnieszka_karczmarczyk@sggw.pl

2) The Regional Directorate of the State Forests in Olsztyn, Department of Forest Infrastructure, 10-959 Olsztyn, ul. Kościuszki 46/48; e-mail: infrastruktura@olsztyn.lasy.gov.pl
}

\begin{abstract}
Forest lodges are often located far from settlements which makes that water supply and sewage treatment problems must be treated in an individual manner. Domestic waste waters from free-standing buildings not connected to sewerage systems should be collected in septic tanks and transported to sewage treatment plants or treated in place of their production in the so-called on-site wastewater treatment plants. Based on data from 33 forest commissions subjected to the Regional Authority of State Forests in Olsztyn an assessment of the equipment of forest lodges in water and waste water infrastructure. Water supply and waste water management was the subject of analyses. From among 795 analysed forest lodges 59\% were supplied in water from the water mains out of which 11 lodges possessed also their own water intake. The remaining $41 \%$ of lodges had their own intakes of potable water. Sixty percent of forest lodges were equipped with septic tanks. Slightly more than a half of them had a contract for waste water disposal, others had bills for such services. From among analysed lodges $18 \%$ were connected to sewer systems and $22 \%$ had on site wastewater treatment plants. Technology of on site wastewater treatment was presented in this paper. Their advantages and disadvantages were discussed and practical solutions to be applied in analysed forest lodges were presented.
\end{abstract}

Key words: infrastructure, sewage treatment, domestic wastewater, forest lodges, water supply

\section{INTRODUCTION}

The main sources of river pollution in Poland are industrial and domestic waste waters and surface runoff. Industrial wastewaters are the main source of dangerous chemicals while domestic sewage and surface runoff from rural areas cause excessive fertilisation of river water by phosphorus and nitrogen.

Poland is one of the European countries poorest in water resources. Small amount of available water is additionally limited by its quality. According to the 
Greenpeace Report on the quality of the Vistula River drainage basin (2008) 35\% of wastewater produced in Poland are treated insufficiently or not treated at all. Presently realised National Programme for Municipal Wastewater Treatment aims at reducing the load of pollutants released to the natural environment till the year 2015. It pertains, however, to pollutants delivered by sewage from towns of population equivalent (PE) over 2000. The reduction of pollutant loads assumed in the programme is aimed to protect European inland waters and to achieve the good ecological status of rivers till the year 2015. It will be accomplished though development, construction and modernisation of sewage treatment plants and collective sewer systems. It does not, however, involve all settlements in Poland. There is still a huge load of pollutants emitted in sewage from areas of dispersed built-up such as rural areas and forests.

Forest lodges inhabited by forest rangers are often built in remote areas, which means that water supply and sewage treatment should be solved in an individual manner. Domestic sewage from free-standing houses might be connected to sewer systems or, if the distance does not permit, should be stored in tight tanks and transported later to treatment plants. An alternative solution might be their on site treatment.

The aim of this paper was to analyse the equipment of forest lodges with the infrastructure which would secure water supply and sewage treatment and to assess the usefulness of selected technologies for domestic sewage treatment.

\section{MATERIAL AND METHODS}

The analysis of water supply and sewage treatment in forest lodges was performed based on data from 13 Forestry Commissions subjected to the Regional Authority of State Forests (RASF) in Olsztyn. Collected data pertained to 469 forest administration regions which included 795 forest lodges. Analysed area covered part of three administration units: warmińsko-mazurskie, mazowieckie and pomorskie voivodships. Persons in charge of infrastructure from particular forest districts answered the questions on water supply (own intake or water pipeline system) and the way of sewage treatment (septic tanks, connection to collective sewer system, on site treatment plants) in their lodges. Additionally, if the lodge was equipped with the septic tank, information on valid contracts for sewage disposal (or on its lack) were also gathered.

The usefulness of selected technologies of sewage treatment for application in on site treatment plants was assessed by comparing them with the use of multicriteria method (BŁAŻEJEWSKI and MAZURKIEWICZ, 2007; RAPACZ, 2008). Comparative analysis was applied to the hydroponic treatment plant localised in the commune Ożarów Mazowiecki and the domestic treatment plant with low charged activated sludge exploited in the commune Jabłonna Lacka. 
In the hydroponic treatment plant EKOPAN (capacity $1 \mathrm{~m}^{3} \cdot \mathrm{d}^{-1}$, surface area 3 $\mathrm{m}^{2}$ ) wastewater are treated by floating biological filter which supports plant roots and provides excellent conditions for the development of biological membrane and diverse community of aquatic microorganisms and invertebrates (RAPACZ, 2008).

In the sewage treatment plant with low charged activated sludge the tank of a capacity $1.5 \mathrm{~m}^{3} \cdot \mathrm{d}^{-1}$ and of total volume of $3 \mathrm{~m}^{3}$ is divided into 3 chambers: primary settling tank, aeration chamber and secondary settling tank. Oxygen is supplied to aeration chamber with compressed air. Compressor is composed of membrane blower, pipes and aerating facilities (GAWRYLUK, 2007).

The efficiency of sewage treatment in selected plants was estimated based on quality indicators $\left(\mathrm{BOD}_{5}, \mathrm{COD}\right.$, total $\mathrm{N}$ and total $\left.\mathrm{P}\right)$ in raw sewage and in the effluent. $\mathrm{BOD}_{5}$ was analysed with the respiration method in Oxi Top apparatus, COD with the dichromate methods, total nitrogen - by persulphate mineralization with chromotropic acid and total P - with the molybdate-vanadium method after mineralization in sulphuric acid. Samples for analyses were taken from primary and secondary settling tanks three times: in November 2006 after 4 months of exploitation and two samples in February 2007 (the treatment plant with activated sludge) and five times in monthly intervals from November 2007 till April 2008 in the third and fourth year of exploitation (hydroponic treatment plant).

\section{RESULTS AND DISCUSSION}

Performed survey provided data on water supply and sewage treatment in all 795 forest lodges in the area of RASF in Olsztyn. Most studied forest lodges (59\%) take water from the water mains including 11 lodges that have additional own but not exploited water intakes. The remaining $41 \%$ of forest lodges use their own drinking water sources (Fig. 1). According to Water Act (Dz.U. $2001 \mathrm{nr}$ 115, poz. 1229) water for household consumption may be taken from own intake (to a depth of $30 \mathrm{~m}$ ) in the amount of no more than $5 \mathrm{~m}^{3} \cdot \mathrm{d}^{-1}$. The same maximum volume of sewage might be treated and disposed to the recipient. The recipients of treated sewage may be water or soil and the conditions on which sewage may be disposed, depending on the type of recipient, are set up in the decree of the Minister of Environment (Dz.U. $2006 \mathrm{nr}$ 137, poz. 984).

Shallow aquifers are the main sources of water supply in individual households in Poland. In small towns and villages water is supplied from own sources or local water mains. Most domestic wells have a depth of less than $20 \mathrm{~m}$. They supply water from aquifers not isolated from above and thus exposed to the input of various anthropogenic pollutants (domestic sewage, natural and mineral fertilisers). In some regions, shallow ground waters are polluted by nitrates, chlorides and ammonium nitrogen and are thus useless for water supply. A specific problem might create the common pollution of shallow waters in dug wells (PERCHUĆ and BORYŃ, 


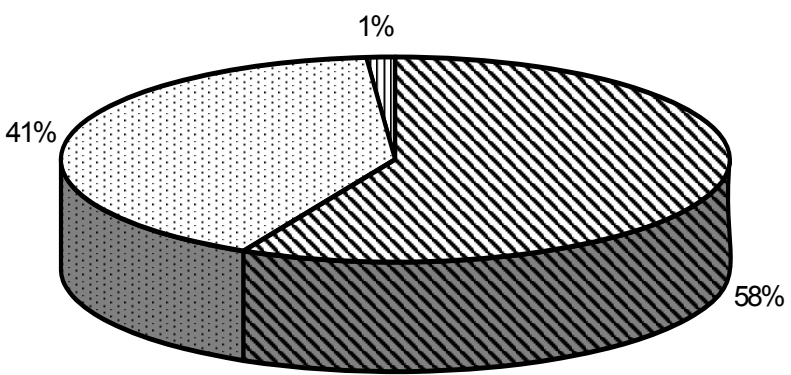

$\mathbf{W}$ water mains own intake

Fig. 1. Water supply - percentage share in analysed forest lodges

2007). In the country scale water for drinking purposes originates mainly (63\%) from groundwater intakes. The largest amount (90\%) of good drinking water is delivered by public water mains; the large ones supply water of the best quality. The percent of good quality water supplied in rural area is estimated at $39.2 \%$ from public intakes, at $61.5 \%$ from company intakes and at $47.6 \%$ from domestic sources (WICHROWSKA et al., 2002). Negative assessment of groundwater quality is a result of exceeded threshold concentrations of iron, manganese and physical properties like turbidity and colour. Individual user has often no idea of chemical pollutants in water since they do not alter its organoleptic features.

Domestic water intakes are often the only available source of water for consumption and other household purposes. Therefore, it is necessary to supply water of appropriate quality and to control it despite the fact that it is not required by legal regulations. This is particularly important for waters taken from shallow depths in which the quality is affected by anthropogenic factors and often by improper technical status of the well (PERCHUĆ and BORYŃ, 2007).

Domestic wastewaters produced in $60 \%$ of analysed forest lodges are stored in septic tanks (Fig. 2). Slightly more than a half of the owners have a contract for waste water disposal to collective treatment plants, others have bills for such services. Having a contract (or its lack) is often a result of local policy in that matter. In principle, acc. to the act on maintaining tidiness and cleanness in communes (Dz.U. $1996 \mathrm{nr} 132$ poz. 622) it is the estate owner's duty to dispose wastewaters which should be documented in a form of a contract with a licensed service provider. However, depending on local conditions, community board may estimate in a special resolution other forms of documenting this duty.

From among analysed forest lodges, $18 \%$ are connected to sewer systems and $22 \%$ are equipped with on site treatment plants (Fig. 2). Effluents from $89 \%$ of domestic treatment plants are discharged to the soil. Unfortunately, obtained results do not allow for estimating the applied technologies of sewage treatment. This deficiency in obtaining specific information in questionnaire survey comes from the 


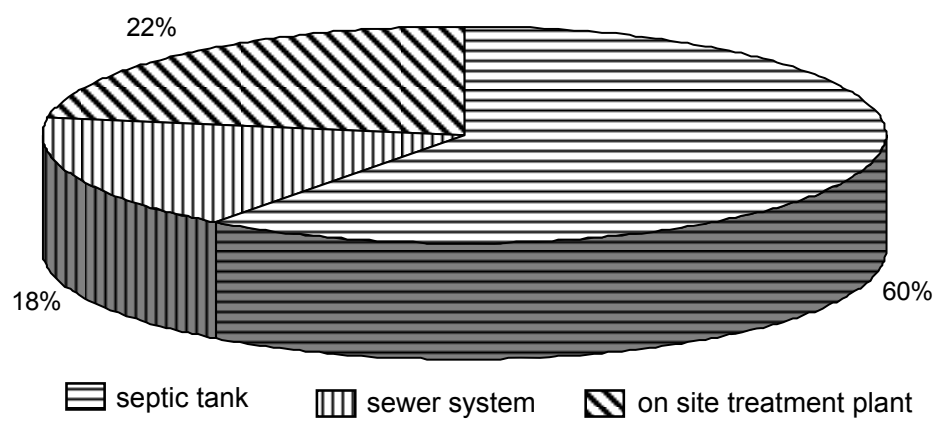

Fig. 2. Management of domestic sewage - percentage share in studied forest lodges

ignorance of technology and from misinformation in the market of on site sewage treatment plants where septic tank with addition of biopreparate is often sold as a biological treatment plant. Estimation of applied technologies needs additional field interviews and surveys in lodges equipped with such facilities.

In practice, selection of technology of wastewater treatment often depends on costs and on a possibility of its adaptation to local conditions. The method of multicriteria analysis, in agreement with the concept of sustainable development, takes into account three basic criteria (economic, social and environmental) and intermediate criteria. This approach considers such important elements like the number of jobs (A), a possibility of recycling water and mineral substances (A/B), annual costs $(B)$, energy consumption $(B / C)$, the efficiency of sewage treatment $(C)$ and exploitation risk (C/A) (BŁAŻEJEWSKI and MAZURKIEWICZ, 2007).

The basis for multi-criteria assessment of on site treatment plants is a set of calculated or estimated criteria variables. Results of an assessment of two selected treatment plants are presented in Fig. 3.

On site treatment plant with activated sludge obtained the mean score of 2.7 and hydroponic plant - 3.2. Less energy is needed to remove $1 \mathrm{~kg}$ of $\mathrm{BOD}_{5}$ in hydroponic treatment plant (criteria $\mathrm{B} / \mathrm{C}$ ). The quality of treated sewage in the EKOPAN plant is definitely better (criteria C). All analysed samples met the requirements from the decree of the Minister of Environment (Dz.U. 2006 nr 137, poz. 984). Investment and running costs (criteria B), exploitation risks (criteria $\mathrm{C} / \mathrm{A}$ ) and recycling of water and mineral compounds (criteria $\mathrm{A} / \mathrm{B}$ ) are similar in both systems. Both systems provide jobs in service and exploitation (criteria A).

The assessment of the efficiency of sewage treatment in on site treatment plants is usually restricted to oxygen indexes and total suspended solids since these indexes are limited in most cases. Tables 1 and 2 present the concentrations of selected parameters in the inflow and outflow from both studied treatment plants.

Hydroponic treatment plant on every sampling date ensured higher than required efficiency of removing organic substances. Oxygen indices in the effluent should not, according to legal regulations, exceed $40 \mathrm{~g} \cdot \mathrm{m}^{-3}$ for $\mathrm{BOD}_{5}$ and $150 \mathrm{~g} \cdot \mathrm{m}^{-3}$ 


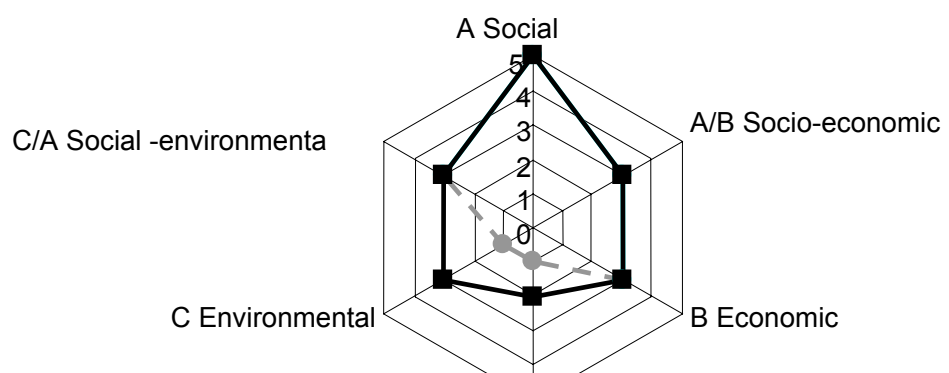

B/C Economic-environmental

\section{- throughflow activated sludge hydroponic treatment plant EKOPAN}

Fig. 3. Comparison of the sewage treatment plant with activated sludge with hydroponic treatment plant (RAPACZ, 2008)

Table 1. Results of analyses of wastewater quality in on site hydroponic treatment plant (RAPACZ, 2008)

\begin{tabular}{l|c|c|c|c|c|r|c|c}
\hline \multirow{2}{*}{$\begin{array}{c}\text { Sampling } \\
\text { period }\end{array}$} & \multicolumn{2}{|c|}{ BOD $_{5}$} & \multicolumn{2}{c|}{ COD $_{\mathrm{Cr}}$} & \multicolumn{2}{c|}{ Total N } & \multicolumn{2}{c}{ Total P } \\
\cline { 2 - 9 } & \multicolumn{8}{c}{$\mathrm{g} \cdot \mathrm{m}^{-3}$} \\
\cline { 2 - 9 } & inflow & outflow & inflow & outflow & inflow & outflow & inflow & outflow \\
\hline XI 2007 & 415 & 6 & 2260 & 96 & 112 & 103.2 & 24.4 & 19.2 \\
XII 2007 & 360 & 9 & 2400 & 63 & 95.6 & 82.0 & 21.3 & 16.9 \\
5I 2008 & 415 & 2 & 1120 & 20 & 108.4 & 103.2 & 17.4 & 12.9 \\
III 2008 & 483 & 5 & 1720 & 32 & 112.8 & 101.6 & 16.4 & 7.1 \\
IV 2008 & 414 & 16 & & & 95.6 & 86.0 & 17.2 & 9.7 \\
\hline
\end{tabular}

Tabela 2. Results of analyses of wastewater quality in on site treatment plant with activated sludge (GAWRYLUK, 2007)

\begin{tabular}{|c|c|c|c|c|c|c|c|c|c|c|}
\hline \multirow{3}{*}{$\begin{array}{c}\text { Sampling } \\
\text { period }\end{array}$} & \multicolumn{2}{|c|}{$\mathrm{BOD}_{5}$} & \multicolumn{2}{|c|}{$\mathrm{COD}_{\mathrm{Cr}}$} & \multicolumn{2}{|c|}{ Total N } & \multicolumn{2}{|c|}{$\mathrm{NH}_{4}$} & \multicolumn{2}{|c|}{ Total P } \\
\hline & \multicolumn{10}{|c|}{$\mathrm{g} \cdot \mathrm{m}^{-3}$} \\
\hline & inflow & outflow & inflow & outflow & inflow & outflow & inflow & outflow & inflow & outflow \\
\hline XI 2006 & 500 & 330 & 558 & 503 & $>100$ & $>100$ & 135 & 150 & 67.8 & 73.8 \\
\hline II 2007 & 420 & 380 & - & - & $>100$ & $>100$ & - & - & 69.9 & 79.3 \\
\hline II 2007 & 420 & 380 & 448 & 478 & $>100$ & $>100$ & 135 & 120 & 38.5 & 44.9 \\
\hline
\end{tabular}

for $\mathrm{COD}_{\mathrm{Cr}}$ and obtained results were several times lower (Tab. 1). The efficiency of sewage treatment in the system with low charged activated sludge (Tab. 2) was very low. It was probably the effect of many factors like e.g. dimensional error (too short retention time), inefficient aeration or improper exploitation. Results presented in Tab. 2 should not be treated as typical for this type of objects since such 
treatment plants happen to operate efficiently even under such unfavourable conditions like individual household services. Presented results have to show that such treatment plants are not easy in exploitation and, even at great owner's involvement, do not bring expected effects (GAWRYLUK, 2007). Therefore, under difficult exploitation conditions (large variability of the hydraulic load and composition of raw wastewaters, frequent breaks in energy supply), less sensitive technologies like e.g. sand filters or constructed wetlands should rather be considered.

Concentrations of nitrogen and phosphorus are not limited in the effluents from small sewage treatment plants except for the cases when the recipient is a lake and its tributaries or water reservoirs on running waters. In such cases the maximum concentrations should not exceed $30 \mathrm{~g} \mathrm{~N} \cdot \mathrm{m}^{-3}$ and $5 \mathrm{~g} \mathrm{P} \cdot \mathrm{m}^{-3}$. Results obtained from both treatment plants show that with such technologies nutrient reduction would be hard to obtain (Tabs 1 and 2). It happened in both sewage treatment plants that concentration of ammonium-nitrogen was higher in the effluent than in raw sewage and the reduction of total nitrogen was very small. The same was true for total phosphorus. Similar results were obtained by KACZOR and BUGAJSKI (2006) who analysed two treatment plants with low charged activated sludge. They explained the observed low efficiency by interrupted work of bioreactors (momentary inflow of concentrated wastewaters), improper age of the sludge (too short retention time - to small volume of aeration chambers) or by infrequent removal of excessive sludge from the bottom of the secondary settling tank (KACZOR and BUGAJSKI, 2006).

Unfavourable operating conditions for on site sewage treatment plants (small volume of waste waters, daily and hourly inequalities in sewage inflows and large variability of concentrations of pollutants) make proper functioning of these plants difficult (PAWELEK et al., 2001). Starting proper operation of the treatment plant with activated sludge i.e. the production of sufficient amount of sludge of adequate quality in the aeration chamber lasts 6 to 12 weeks (KALENIK, 2004) and every break needs re-starting. When assessing small rural sewage treatment plants one should keep in mind these specific conditions supplemented also by the level of their exploitation. Basic rules of exploitation that would secure proper functioning of container treatment plants include appropriate control and maintenance, constant supply of electric energy to all facilities and preventing from single inputs of large amounts of waste waters and from breaks in the sewage inflow for more than one day (KALENIK, 2004).

\section{SUMMARY}

Technologies of on site treatment plants discussed in the paper were restricted to two variants. The treatment plant based on activated sludge is a miniaturised form of conventional technology used in sewage treatment in large towns. The ad- 
vantage of this technology is small area occupied by treatment plant and the disadvantage - the need of constant supply of electric power to aerate wastewaters. Activated sludge is also sensitive to variations in the amount and quality of treated sewage. Hydroponic treatment plants are the modification of constructed wetlands where plants and microorganisms dwelling their rhizosphere play an important role. However, there are a lot of other technologies; some of them even more popular. Most often used, mainly because of low costs, is the soil infiltration (score 3.0 acc. to the evaluation system of BŁAŻEJEWSKI and MAZURKIEWICZ (2007)) offered by distributors as a biological treatment plant though in fact it is a mechanical treatment facility (septic tank) with the effluent discharged to the soil. Basic purification processes take place on soil particles. Such technology does not allow for controlling the quality of treated sewage which is its undeniable drawback. Other solutions which might be commonly used include sand filters (score 3.7) and subsurface flow constructed wetlands. Both are highly efficient in removing organic substances and are particularly recommended in areas with problems in providing constant supply of electric energy. Their basic flaw is relatively large unit area needed to treat sewage. There are also many less typical solutions which pay more attention to removing phosphorus and nitrogen from sewage (KARCZMARCZYK, 2000; RENMAN and BROGOWSKI, 2004; JOHANSON, 2006). These solutions are not popular now due to a lack of legal motivation (concentrations of $\mathrm{N}$ and $\mathrm{P}$ in the effluent from on site treatment plants are not limited). In this paper we decided to present these technologies which are now widespread in areas of dispersed built-up such as in the commune Ożarów Mazowiecki with 21 on site wastewater treatment plants and 3 hydroponic treatment plants serving the housing estates (RAPACZ, 2008), or in the commune Belsk Duży, where 100 ZBF treatment plants (activated sludge with fluid bed) with the capacity of $5 \mathrm{~m}^{3} \cdot \mathrm{day}^{-1}$ were installed in 2007 . Each of them treats the sewage from several households due to lower costs of investment and exploitation (BADOWSKA, 2008). There are 2000 on site treatment plants exploited now in łódzkie voivodship and 1600 new objects are planned to be installed in the years 2008-2013 there (GŁADYSZ, 2008). Programmes of building on site treatment plants arouse interest in rural inhabitants. The total number of on site sewage treatment plants in rural areas in Poland reached 32.5 thousand in 2006 (Ochrona..., 2007).

Despite the fact that still many clients choose on site treatment plants upon their price, the quality, service offered by provider (project, transport, and installation), the terms of warranty and availability of facilities become more and more important. Clients ask more often for effluent parameters which is the evidence of rising interest in environmental issues.

The analysis presented in this paper showed that in the case of improper functioning of on site wastewater treatment plant the concentrations of ammoniumnitrogen, total nitrogen and phosphates might be very high. Considering that eutrophication of waters, including those of the Baltic Sea, is largely enhanced by nutri- 
ents input from dispersed sources, the Helsinki Commission issued a recommendation for sewage treatment plants in individual households, small firms and housing estates of up to 300 person equivalents adopted in November 2007. The Helsinki Commission recommends the reduction of nutrient outflow from these sources mainly through a ban for disposal of raw wastewaters and limiting unit emissions of the load of $\mathrm{BOD}_{5}$ to $8 \mathrm{~g} \cdot \mathrm{PE}^{-1} \cdot \mathrm{d}^{-1}$, total $\mathrm{P}$ to $0.65 \mathrm{~g} \cdot \mathrm{PE}^{-1} \cdot \mathrm{d}^{-1}$ and total $\mathrm{N}$ to 10 $\mathrm{g} \cdot \mathrm{PE}^{-1} \cdot \mathrm{d}^{-1}$. For households of high standard of equipment it means average reduction of $\mathrm{BOD}_{5}$ by $80 \%$, total P by $70 \%$ and total $\mathrm{N}$ by $29 \%$ (HELCOM..., http).

The equipment of forest lodges in the area of RASF in Olsztyn in water supply and sewage treatment facilities is good. One should underline the need of controlling water quality in wells which serve as water sources for $41 \%$ of forest lodges. Due to remote location of forest lodges, their joining to sewer systems is often impossible. Performed studies showed that such solution was applied in only $18 \%$ of lodges. There is, however, a potential for the construction of on site sewage treatment plants as an alternative for septic tanks which are used in $60 \%$ of lodges. These plants should be based on technologies using ecologic engineering methods i.e. sand filters or soil-plant beds well-tried under conditions of uneven flow and periodic breaks in energy supply.

\section{REFERENCES}

1. BADOwSKA J., 2008. Analiza stanu i perspektywy rozwoju gospodarki ściekowej na terenie gminy Belsk Duży. Warszawa, SGGW pr. dypl. maszyn.: 47.

2. BŁAŻEJEWSKI R., MAZURKIEWICZ J., 2007. Wybór małej oczyszczalni ścieków dla terenów niezurbanizowanych. Gaz Woda Tech. Sanit., 1: 22-26.

3. GAWRYLUK R., 2007. Kształtowanie zasobów wodnych dla zachowania walorów przyrodniczych gminy Jabłonna Lacka. Warszawa, SGGW pr. magist. maszyn.: 111.

4. GŁADYSZ R., 2008. Działania w zakresie budowy indywidualnych wiejskich oczyszczalni ścieków w województwie łódzkim. Gaz Woda Tech. Sanit. 5: 37-41.

5. Ochrona Środowiska, 2007. Warszawa, GUS: www.stat.gov.pl

6. HELCOM recommendation $28 \mathrm{E} / 6$. On-site wastewater treatment of single family homes, small businesses and settlements up to 300 Person Equivalents (P.E.): http://www.helcom.fi

7. JOHANSON L., 2006. Substrates for phosphorus removal - Potential benefits for on-site wastewater treatment? Water Res., 40, 1: 23-36.

8. KACZOR G., BUGAJSKI P., 2006. Ładunki związków biogennych w ściekach odprowadzanych z przydomowych oczyszczalni jako zagrożenie jakości wód powierzchniowych. Gaz Woda Tech. Sanit. 11: 21-23.

9. KALENIK M., 2004. Projektowanie i budowa przydomowych oczyszczalni ścieków. Inf. Nauk. Tech., 13: 48-58.

10. KARCZMARCZYK A., 2000. Influence of some properties of potential sorbent on P-removal from domestic wastewater. Ann. Wars. Agricult. Univ. - SGGW, Land Reclam., 30: 59-65.

11. Pawelek J., DŁugosz M., Kaczor G., 2001. Wiejskie oczyszczalnie ścieków w województwie małopolskim na przykładzie powiatów bocheńskiego i limanowskiego. Zesz. Nauk. AR Krak., 390, Inż. Środ., 22: 107-120.

12. Perchú́ M., Boryń A., 2007. Problemy przydomowego zaopatrzenia w wodę. Gaz Woda Tech. Sanit., 7-8: 28-34. 
13. RAPACZ M., 2008. Ocena efektywności lokalnych systemów oczyszczania ścieków na przykładzie wybranych hydroponicznych oczyszczalni ścieków w gminie Ożarów Mazowiecki. Warszawa, SGGW pr. magist. maszyn.: 91.

14. Raport Greenpeace o stanie czystości dorzecza Wisły „Rzeka nie jest ściekiem”, 2008. Warszawa, Greenpeace: http://www.greenpeace.org

15. RENMAN G., BROGOWSKI Z., 2004. Characterisation of opoka as a basis for its use in wastewater treatment. Pol. J. Env., 13, 1: 15-20.

16. WichrowsKa B., KozŁowsKa E., KozŁOWSKi J., 2002. Ocena jakości wody przeznaczonej do spożycia, Instal. 5: 16-22.

\section{STRESZCZENIE}

\section{Potrzeby i możliwości budowy przydomowych oczyszczalni ścieków w zagrodach leśnych}

Słowa kluczowe: infrastruktura, oczyszczanie, ścieki bytowe, zagrody leśne, zaopatrzenie $w$ wode

Zagrody leśne, szczególnie leśniczówki i podleśniczówki, są często znacznie oddalone od osad, co powoduje, że problem zaopatrzenia w wodę i zagospodarowania ścieków mieszkańcy muszą rozwiązywać w sposób indywidualny. Ścieki bytowe $\mathrm{z}$ wolnostojących budynków, niepodłączonych do zbiorczej sieci kanalizacyjnej powinny być gromadzone w szczelnych zbiornikach i wywożone do grupowych oczyszczalni lub też oczyszczane w miejscu ich powstawania, w tzw. przydomowych oczyszczalniach ścieków (POŚ). Na podstawie informacji pochodzących z 33 nadleśnictw na terenie RDLP w Olsztynie przeprowadzono ocenę stanu wyposażenia zagród leśnych $\mathrm{w}$ infrastrukturę wodno-ściekową. Przedmiotem analizy był sposób zaopatrzenia w wodę oraz zagospodarowania ścieków. Spośród 795 analizowanych zagród leśnych $59 \%$ zaopatrywane jest w wodę $\mathrm{z}$ sieci wodociagowej, w tym 11 zagród posiada również własne ujęcie wody. Pozostałe $41 \%$ zagród ma własne ujęcia wody pitnej. $60 \%$ zagród leśnych wyposażone jest w szczelne zbiorniki na ścieki. Nieco ponad połowa z nich ma podpisane umowy na wywóz ścieków do oczyszczalni, pozostałe takich umów nie mają natomiast posiadają faktury za wywóz. Spośród analizowanych zagród $18 \%$ jest podłączone do zbiorczej sieci kanalizacyjnej, a $22 \%$ posiada przydomowe oczyszczalnie ścieków. Przedstawiono technologie przydomowego oczyszczania ścieków. Przedyskutowano ich wady i zalety oraz wskazano rozwiązania do zastosowania $\mathrm{w}$ analizowanych zagrodach.

Reviewers:

Prof. Franciszek Czyżyk

Assist. prof. Tadeusz Siwiec 